\title{
ОРГАНІЗАЦІЙНЕ ЗАБЕЗПЕЧЕННЯ РАЦІОНАЛЬНОї РЕАЛІЗАЦІЇ ПОТЕНЦІАЛУ ПЦДПРИЕМСТВА
}

\author{
ЩЕБЕЛЬ А.І. - викладач кафедри економіки підприсмств та інформаційних \\ технологій Львівського університету бізнесу та права \\ https://orcid.org/0000-0002-7074-5783 \\ DOI:10.32782/LAW.2020.1.27
}

В статье, помимо традиционнъх компонентов организачионного обеспечения (бормирование организационной структурь управления, создание правил и прочедур в организачии, распределение бункицй и полномочий в системе кадров), рассмотрен механизм развития креативнъгх инициатив в управлении потенциалом предприятия. Доказано, что эта компонента каузально связана с другими составляюшими организачионного обеспечения раџиональной реализачии потенциала предприятия. Обосновано, что ее использование въгзвано активизированием интеграционньх процессов, повъпшением уровня информатизации бизнеса и обострение конкуренции. Построенная модель организачионного обеспечения требует учета бакторов, которые являются общими для всех ее компонентов. В частности, при принятии локальных решений в центрах ответственности, относящиеся к определенному компоненту системьл. Организачионное развитие предприятия в значительной степени связано с фазой жизненного цикла предприятия. Каждая из компонент системъ множеств организационного обеспечения рациональности реализачии потенииала предприятия является активной в течение всего жизненного ицила развития предприятия. Но наступление заключительной базы развития является признаком отсутствия или слабости построенного на предприятии механизма развития креативньлх инициатив в управлении потенциалом предприятия. Обосновано, что параметрь модели организачионного обеспечения рачиональной реализации потеничала предприятия требует количественной параметризачии, особенно для принятия обоснованньхх решений, связанных с управлением потенциалом по базам жизненного иикла предприятия. Доказано, ито дальнейшие исследования целесообразно проводить в направлении разработки системъг мониторинга и регулирования управленческих решений по реализачии потенциала предприятия.

Ключевъе слова: потенииал, организачионное обеспечение, предприятие, управление, рачиональность.

\section{Постановка проблеми}

Досягнення раціональності у реалізації потенціалу підприємства вимагає організаційного, інформаційно-комунікаційного, кадрового, матеріально-технічного та інших видів забезпечення. Організаційне забезпечення, як правило, охоплює кілька векторів, а саме: формування організаційної структури управління, створення правил i процедур в організації, розподіл функцій i повноважень у системі кадрів. Попри те, що в розрізі цих векторів виконано досить багато наукових досліджень? слід визнати, що серед них $є$ мало таких, які стосуються організаційного забезпечення потенціалу підприємства. Крім того, науковці не враховують те, що в умовах активізування інтеграційних процесів, підвищення рівня інформатизації бізнесу і загострення конкуренції поняття «організаційне забезпечення» виходить за межі традиційних векторів. Враховуючи це, проблема полягає у фрагментарності сучасних теоретико-методичних 
положень до моделювання організаційного забезпечення раціональної реалізації потенціалу підприємства.

\section{Аналіз останніх досліджень і публікацій}

Дослідження, які присвячені висвітленню проблем організаційного розвитку, мають досить широкий спектр предметів, які вони висвітлюють. Попри це їх можна поділити на ті, які стосуються виключно теоретичних аспектів організаційного розвитку [1], [2], i ті, які мають глибоко прикладний фокус. На сьогодні більшість досліджень належить саме до другої групи. Так, автори, які досліджують організаційний розвиток, розглядають його в системі оцінювання кредитоспроможності підприємств [3], як етап технології фінансово-аналітичного забезпечення управлінської діяльності [4], компоненту легітимізації застосування безпілотних повітряних суден [5], інструментарій управління інноваційноактивним підприємництвом [6], інструмент подолання деструктивних явищ в управлінні персоналом компаній на основі емпіричного [7] та експертного [8] оцінювання та аналізу даних [9], [10].

\section{Цілі статті}

Метою статті є побудувати модель організаційного забезпечення раціональної реалізації потенціалу підприємства. Для досягнення цієї цілі необхідно виконати такі завдання:

· ідентифікувати компоненти і елементи моделі;

• встановити зв'язки між компонентами і елементами моделі;

· визначити умови ефективності функціонування моделі.

\section{Виклад основного матеріалу дослідження}

Організаційне забезпечення раціональності реалізації потенціалу підприємства має кілька складових, а саме:

- організаційну структуру управління потенціалом підприємства $(\bigcup S)$;

- правила і процедури управління потенціалом підприємства $(U P)$;
- систему розподілу функцій і обов'язків між менеджерами, що беруть участь в управлінні потенціалом підприємства $(U F)$;

- механізм розвитку креативних ініціатив в управлінні потенціалом підприємства $(\bigcup M)$.

У сукупності ці компоненти формують систему множин організаційного забезпечення раціональності реалізації потенціалу підприємства $(\bigcup Z)$, яку у формалізованому вигляді напишемо так:

$$
\left.\begin{array}{l}
\bigcup Z=\bigcup S \cup \bigcup P \cup \bigcup F \cup \cup M ; \\
s \in \bigcup S \Leftrightarrow \exists Z \in S, s \in Z ; \\
p \in \bigcup P \Leftrightarrow \exists Z \in P, p \in Z ; \\
f \in \bigcup F \Leftrightarrow \exists Z \in F, f \in Z ; \\
m \in \bigcup M \Leftrightarrow \exists Z \in M, m \in Z,
\end{array}\right\}
$$

$s$ - підмножина елементів множини $\bigcup S$; $p$ - підмножина елементів множини $U P$; $f$ - підмножина елементів множини $\bigcup F ; m-$ підмножина елементів множини $\bigcup M$.

Підмножина $s$ включає в себе постійні структурні підрозділи $\left({ }^{S_{1}}\right)$, робочі групи і комісії в системі управління потенціалом підприємства $\left({ }^{S_{2}}\right)$, а також робочі групи i комісії, які створюються тимчасово для реалізації певних управлінських ініціатив або розв'язання виявлених проблем $\left({ }^{S_{3}}\right)$, тобто $\left(s_{1} ; s_{2} ; s_{3}\right) \subset \mathrm{s}$. Слід відзначити, що однією 3 характеристик розвинутої організаційної структури управління потенціалом підприємства 6 іï ієрархічність, яка виявляється у виникненні рівнів управління - вищий ( $\left.\bigcup S_{v}\right)$, середній ( $\left.U S_{s}\right)$ і низовий $\left(U S_{n}\right)$, а також відносин субординації між менеджерами різних рівнів управління (рис. 1)

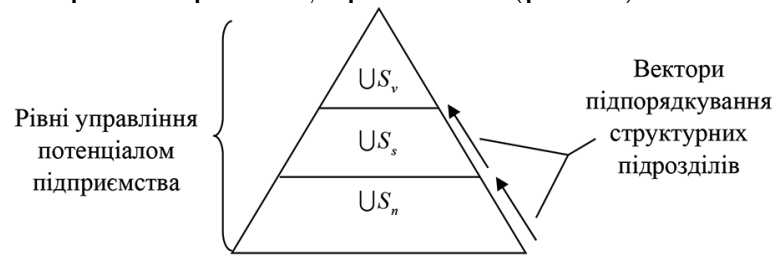

Рис. 1. Ієрархія в організаційні структурі управління потенціалом підприємства

Примітки: побудовано дисертантом 


\section{Цивільне, підприсмницьке, господарське та трудове право}

У формалізованому вигляді характеристику ієрархічності організаційної структури управління потенціалом підприємства запишемо так:

$$
\left.\begin{array}{l}
\bigcup S_{v} \supset \bigcup S_{s} \supset \bigcup S_{n} ; \\
S_{1.1} \ldots S_{1 . n} \subset \bigcup S_{v} ; \\
S_{2.1} \ldots S_{2 . n} \subset \bigcup S_{s} ; \\
S_{3.1} \ldots S_{3 . n} \subset \bigcup S_{n},
\end{array}\right\}
$$

$S_{1.1} \ldots S_{1 . n}$ - структурні елементи організаційної структури управління потенціалом підприємства на вищому рівні управління; $S_{2.1} \ldots S_{2 . n}$ - структурні елементи організаційної структури управління потенціалом підприємства на середньому рівні управління; $S_{3.1} \ldots S_{3 . n}$ - структурні елементи організаційної структури управління потенціалом підприємства на низовому рівні управління.

Підмножина $p$ також включає в себе кілька елементів - $\left(p_{1} ; p_{2} ; p_{3}\right) \subset p$, де $p_{1}$ - система положень про структурні підрозділи, на які покладено функції управління потенціалом підприємства; $p_{2}$ - система посадових інструкцій у розрізі структурних підрозділів, на які покладено функції управління потенціалом підприємства; $p_{3}$ - інструкції, пов'язані із реалізацією певних загально корпоративних заходів у системі управління потенціалом підприємства.

Підмножина $f$ включає такі компоненти, як базу даних із розподілу функцій між структурними підрозділами підприємства щодо управління потенціалом підприємства $\left(f_{1}\right)$, а також базу даних щодо розподілу функцій і повноважень піж менеджерами, які беруть участь в управлінні потенціалом підприємства, тобто $\left(f_{1} ; f_{2}\right) \subset f$.

Складовими елементами підмножина $m$ є структурний підрозділ, робоча група або комісія, функцією яких є керівництво процесом розвитку креативних ідей у сфері управління потенціалом підприємства $\left({ }^{m_{1}}\right)$, правила і процедури керівництва процесом розвитку креативних ідей у сфері управління потенціалом підприємства $\left({ }^{m}\right)$, а також система цілей у системі керівництва процесом розвитку креативних ідей $\left({ }^{m_{3}}\right)$, яка реалізовується через розподіл функцій і повноважень між менеджерами підрозділу $m_{1}$. Отож, $\left(m_{1} ; m_{2} ; m_{3}\right) \subset m$.

Виходячи зі структури підмножини $m$ бачимо, що в системі організаційного забезпечення раціональності реалізації потенціалу підприємства має місце перетин окремих ії компонентів, а саме

$$
\begin{aligned}
& \bigcup M \cap \bigcup P=\left\{m_{1} \mid m_{1} \in \bigcup M \wedge m_{1} \in \bigcup P\right\} ; \\
& \bigcup M \cap \bigcup S=\left\{m_{2} \mid m_{2} \in \bigcup M \wedge m_{2} \in \bigcup S\right\} ; \\
& \bigcup M \cap \bigcup F=\left\{m_{3} \mid m_{3} \in \bigcup M \wedge m_{3} \in \bigcup F\right\} . \\
& \text { Отже, } \because(\bigcup \grave{S} \cup \backslash \not P \cup \backslash \not F) \cap \bigcup \quad \therefore \quad \square \cap \text {. }
\end{aligned}
$$

На рис. 2 наведено графічну модель організаційного забезпечення раціональності реалізації потенціалу підприємства.

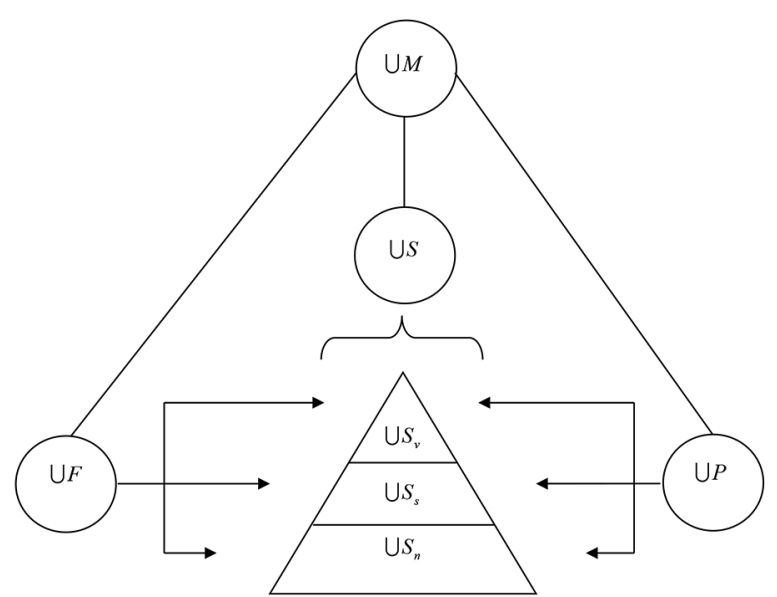

Рис. 2. Модель організаційного забезпечення раціональності реалізації потенціалу підприємства

Примітки: побудовано автором статті

Побудована модель вказує на те, що на систему організаційного забезпечення раціональності реалізації потенціалу підприємства впливають фактори, які є спільними для кількох компонент. Цю обставину важливо враховувати під час прийняття локальних рішень на конкретних ієрархічних рівнях управління, зокрема в центрах відповідальності, які стосуються певного компонента системи. Наприклад, нехай заступник директора з креативного розвитку встановив певну нереалістичну ціль. Це не- 
Щебель А.І. - Організаційне забезпечення раціональної реалізації потенціалу...

минуче відобразиться на цілях начальника відділу креативного розвитку (середній рівень управління) і завданнях креаторів (лідерів робочих груп на низовому рівні управління). Через нереалістичність поставленого завдання можуть відбуватись нераціональні дії стосовно стимулювання креативних груп до більш продуктивної роботи, залучення креаторів на умовах аутсорсингу тощо. Для уникнення негативних ефектів від перетину множин у системі організаційного забезпечення раціональності реалізації потенціалу підприємства необхідним 6 :

- перманентний моніторинг внутрішнього і зовнішнього середовищ, у яких формується потенціал підприємства;

· забезпечення прозорості у виявленні і розв'язанні проблем досягнення раціональності в управлінні потенціалом підприємства;

уникнення суб'єктивізму у виборі оптимальних рішень щодо досягнення раціональності в управлінні потенціалом підприємства шляхом практикування колегіального вироблення рішень і застосування автоматизованих інформаційних технологій для обробки управлінської інформації. Тут, зокрема йдеться про сучасні системи підтримки прийняття рішень, для яких характерним є: надання керівнику допомоги у процесі прийняття рішень і забезпечення підтримки у всьому діапазоні контекстів задач; підтримка і посилення міркування та оцінки керівника; підвищення ефективності прийняття рішень; виконання інтеграції моделей і аналітичних методів із стандартним доступом до даних і вибіркою 3 них; проста в роботі для осіб, що мають досвід роботи 3 ЕОМ; побудова за принципом інтерактивного розв'язання задач; орієнтація на гнучкість і адаптивність для пристосування їх до змін середовища або модифікації підходів до розв'язання задач, які обирає користувач тощо [11], [12].

Організаційний розвиток підприємства значною мірою пов'язаний із фазою життевого циклу підприємства (рис. 3).

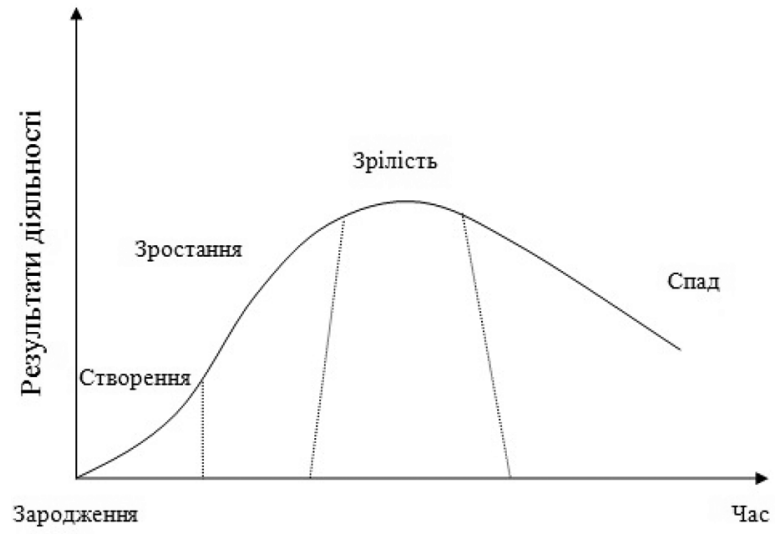

Рис. 3. Життєвий цикл розвитку підприемства

Джерело: [13]

Кожна із компонент системи множин організаційного забезпечення раціональності реалізації потенціалу підприємства є активною упродовж усього життєвого циклу розвитку підприємства, проте слід визнати, що настання завершальної фази розвитку є ознакою відсутності або слабкості побудованого на підприємстві механізму розвитку креативних ініціатив в управлінні потенціалом підприємства ( $U M$ ). Зінкевич Д. розглядає креативну діяльність як: «...діяльність пройняту елементами нового, вдосконалення, збагачення, розвитку ....., а розвиток як процес, у наслідок якого відбувається зміна якості чого-небудь, перехід від одного якісного стану до іншого, вищого [14], то під розвитком системи креативного менеджменту доцільно розуміти процес систематизації сучасної і створення нової наукової і технологічної інформації, яка дозволяє розв'язувати виробничо-господарські проблеми, знижувати їх гостроту або вказувати спосіб ліквідації наслідків виявлених проблем...» [15]. Автор переконаний, що «...удосконалення чинних систем креативного менеджменту $є$ найбільш результативними, якщо вони реалізовуються не як разовий акт, а в межах певної стратегії, що передбачає дотримання низки послідовних етапів реалізації, дотримання яких керівниками систем креативного менеджменту ... сприятиме їх раціональності, узгодженості та результативності...» [16].

В умовах ефективного функціонування механізму розвитку креативних ініціатив в управлінні потенціалом підприємства фаза зростання і зрілості, під впливом ринкової 


\section{Цивільне, підприємницьке, господарське та трудове право}

кон'юнктури і рівня загострення конкуренції, періодично повинні були 6 змінювати одна одну. Це означає, що раціональність реалізації потенціалу підприємства повинна була 6 відтворюватись або набувати додатного приросту. Розглянемо це на прикладі продуктивності праці, як показника, що характеризує раціональність реалізації потенціалу підприємства:

$$
\left.\begin{array}{l}
\bigcup W_{b}=O_{b} \cup T ; \\
\cup W_{z}=O_{z} \cup T ; \\
\bigcup W_{b} \cap \bigcup W_{z}=\left\{T \mid T \in \bigcup W_{b} \wedge T \in \bigcup W_{z}\right\} ; \\
\bigcup W_{z} / \bigcup W_{b} \square \Delta, \Delta \geq 0,
\end{array}\right\}
$$

де $O_{b}, O_{z}$ - обсяги виробництва у базовому і звітному періодах, шт.; $T$ - тривалість періодів, рік; $\bigcup W_{b}, \bigcup W_{z}$ - множини показників, які характеризують продуктивність праці у базовому і звітному періодах; $\Delta$ - приріст продуктивності праці у звітному періоді у порівнянні з базовим, шт. / рік.

На рис. 4 наведено залежності між факторними і результативними показниками, які характеризують раціональність реалізації потенціалу підприємства. 3 рис. 4 бачимо, якщо умови (4) не витримуються і $\Delta$ набуває від'ємного приросту (рис. 4, а), то менеджери підприємства, зокрема ті, як здійснюють управління потенціалом підприємства повинні знизити обсяг адміністративних витрат (рис. 4, б), активізувати креативно-інноваційну діяльність (рис. 4, в) i збільшити витрати на реалізації креативних заходів і впровадження інновацій (рис. 4, г).
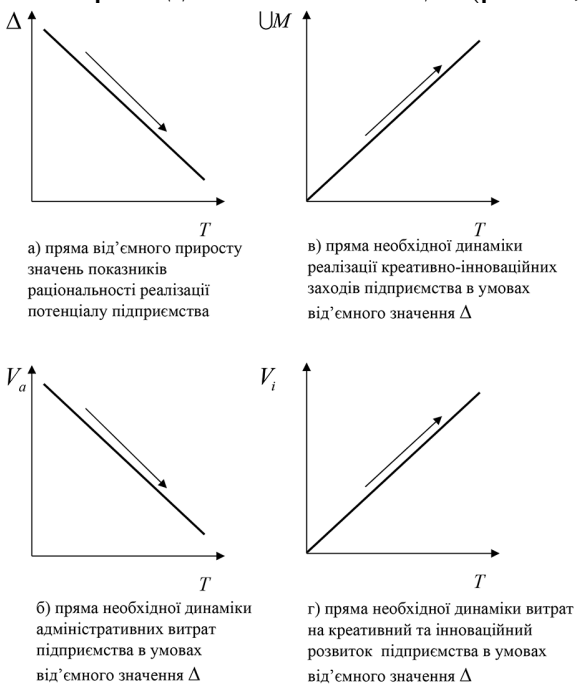

Рис. 4. Залежності між факторними і результативними показниками, які харак- теризують раціональність реалізації потенціалу підприємства

Примітки: побудовано автором статті

Отже, D - це результуючий параметр, а $T i^{V_{i}}$ - фактори, від яких залежить D. Наведемо економіко-математичну модель, яка відображатиме залежності між цими параметрами, де значення функції визначені в межах від 0 до $\infty$, і результуючий параметр має змінюватись залежно від характеру взаємозв'язку між досліджуваними параметрами

$$
\Delta=f\left(T, V_{i}\right) \Rightarrow \Delta=\alpha T^{\beta} V_{i}^{\theta},
$$

де $\alpha, \beta, \theta$ - степеневі регресійні коефіцієнти.

Шляхом перетворення рівняння $\Delta=\alpha T^{\beta} V_{i}^{\theta}$ у лінійно-логарифмічну форму за допомогою методу найменших квадратів і застосування операції потенціювання (позбавленні математичного виразу логарифмів 3 метою його спрощення) можна обчислити степеневі регресійні коефіцієнти:

$$
\left.\begin{array}{l}
\ln (Y)=a_{0}+a_{1} \ln (T)+a_{2} \ln \left(V_{i}\right) ; \\
\ln (Y)=a_{0}+\beta \ln (T)+\theta \ln \left(V_{i}\right) \Rightarrow \\
\ln (Y)=\ln (\alpha)+\ln \left(T^{\beta}\right)+\ln \left(V_{i}^{\theta}\right) \Rightarrow \\
\ln (Y)=\ln \left[\alpha T^{\beta} V_{i}^{\theta}\right] \Rightarrow Y=\alpha T^{\beta} V_{i}^{\theta},
\end{array}\right\}
$$
ciï.

де $a_{0}, a_{1}, a_{2}$-лінійні коефіцієнти регре-

Отже, використовуючи метод найменших квадратів та низки математичних перетворень, можливим є отримання степеневої залежності, необхідної для дослідження динаміки приросту значень показників раціональності реалізації потенціалу підприємства, а також аналізу впливу на цю динаміку фактора часу і обсягу витрат на креативний та інноваційний розвиток підприємства.

Проаналізуємо наведену вище економіко-математичну модель на перспективну динаміку досліджуваних факторних і результативного показників. Під час аналізу врахуємо можливі похибки даних (оскільки значення, отримані в результат застосування 
моделі (5), можуть виявитись як більшими так і меншими відносно фактичних значень, то похибки можуть бути меншими нуля, що призводить до неадекватного їх зважування на основі лінійних коефіцієнтів. Розв’язання цієї проблеми можливе шляхом піднесення до квадрата від'ємних значень), а також їх вплив на D i їі дисперсію. У результаті отримаємо таке рівняння:

$$
\sigma_{t}=x_{0}+x_{1}\left|y_{t-1}\right|+x_{2}\left|y_{t-2}\right|+\ldots+x_{z}\left|y_{t-z}\right|=x_{0}+\sum_{i=1}^{z} x_{i}\left|y_{t-i}\right|,
$$

де ${ }^{\sigma_{t}}$ - дисперсія результуючого параметра, розрахована за період часу $t ; x_{0}, x_{1}, \ldots$, $x_{z}$ - лінійні коефіцієнти регресійні; $y_{t-1}, \ldots$,

$y_{t-z}$ - ряди похибок із зсувом у часі від 1 до z періодів; z - найбільша кількість періодів, для яких можливим є зсув.

\section{Висновки і перспективи подадьших досліджень}

Отримана модель дає змогу суб'єктам управління потенціалом підприємства встановити, яким чином значення похибок впливають на відхилення D від середнього значення. На основі цього можна дійти таких висновків:

1) вплив похибок на дисперсію вказує на те, що чим вищий рівень невизначеності для досліджуваної стохастичної величини, тим більшими є коливання, тим сильнішим є вПлив рефлексивності;

2) при відсутності або низькому впливі похибок на дисперсію рефлексивність не впливає на динаміку D;

3) значення коефіцієнтів регресії для моделі (7) дають уявлення про те, 3 яким періодом зростання невизначеності відображається на дисперсії випадкової величини, що дає змогу показати, на скільки «розтягнутим» у часі $\epsilon$ вплив рішень менеджерів, залучених до управління потенціалом підприемства.

Подальші дослідження доцільно проводити у напрямку розроблення системи моніторингу i регулювання управлінських рішень щодо реалізації потенціалу підприємства.

\section{Мiтература}

1. Legeza, N. V. (2019), "Theoretical aspects of the organizational support of development enterprise", Efektyrna ekonomika, [Online], vol. 1, available at: http://www. economy.nayka.com.ua/?op $=1 \& \mathrm{z}=6855$ (Accessed 16 Apr 2020). DOI: 10.32702/23072105-2019.1.151

2. Chernyavska, I. (2019). Organizational Support for Industrial Restructuring at Metallurgical Enterprises. Modern Economics, 13(2019), 259-265. DOI: https://doi. org/10.31521/modecon.V13(2019)-40.

3. Виговська Н., \& Виговський В. (2017). Розвиток організаційного забезпечення аналізу кредитоспроможності позичальникаюридичної особи. «Вісник ЖДТУ»: Економіка, управління та адміністрування, 1(79), 142150. doi:http://dx.doi.org/10.26642/jen-20171(79)-142-150

4. Яценко, В., Яценко, О., Яценко, М., \& Ткачук, I. (2017). Інформаційно-організаційне забезпечення побудови і аналізу фінансової звітності, значення іiі аналітичних показників в управлінні підприємницькою діяльністю. Збірник наукових пращь Черкаського державного технологічного університету. Се-

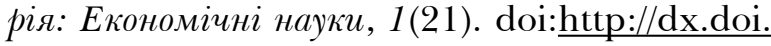
org/10.24025/2306-4420.1.21.2008.88301

5. Стрільців , О. 2019. Напрями правового врегулювання та організаційного забезпечення використання безпілотних повітряних суден в Україні на сучасному етапі. Юридичний часопис Національной академіӥ внутрішніх справ. 18, 2 (Вер 2019), 116-124. DOI:https://doi.org/10.33270/04191802.116.

6. Zaychenko, K. (2019), "Methods and models of formation the organizational structure of innovation-active small enterprise: essence and practical value", Ekonomika ta derzhava, vol. 2, pp. 135-140. DOI: 10.32702/23066806.2019 .2 .135

7. Bohle, Sergio Andrés López, Chambel, Maria José, Medina, Felipe Muñoz, \& Cunha, Bruno Silva Da. (2018). The role of perceived organizational support in job insecurity and performance. Revista de Administração de Empresas, 58(4), 393-404. https://doi. org/10.1590/s0034-759020180405

8. Kurtessis, JN, Eisenberger, R., Ford, MT, Buffardi, LC, Stewart, KA, \& 


\section{Цивільне, підприємницьке, господарське та трудове право}

\section{АНОТАЦІЯ}

У статті, крім традииійних компонентів організачійного забезпечення (бормування організачійної структури управління, створення правил $і$ процедур в організащиї, розподіл функиій $i$ повноважень у системі кадрів), розглянуто механізм розвитку креативних ініціатив в управлінні потениіалом підприємства. Доведено, що ия компонента каузально пов'язана з іншими складовими організачійного забезпечення рачіональної реалізачй потенизалу підприємства. Обгрунтовано, що ї̈ обліку викликано активізування інтеграчійних процесів, підвищенням рівня інборматизащї бізнесу $i$ загострення конкурениї. Побудована модель організачійного забезпечення вимагає врахування чинників, які $є$ загальними для всіх ї̈ компонентів. Зокрема, при прийнятті локальних рішень у центрах відповідальносmi, пов'язані з певного компонента системи. Організаиійний розвиток підриємства в значній мірі пов'язаний з базою життєвого изиклу підприємства. Кожна з компонент системи множин організаційного забезпечення раціональності реалізациї потенціалу підприємства є активною протягом усъого життєвого изиклу розвитку підприємства. Але настання завершальної бази розвитку є ознакою відсутності або слабкості побудованого на підприємстві механізму розвитку креативних ініціатив в управлінні потенціалом підприємства. Обгрунтовано, що параметри моделі організаиійного забезпечення раціональної реалізацї потенціалу підприємства вимагають кількісної параметризаиій, особливо для прийняття обгрунтованих рішень, пов'язаних 3 управлінням потенціалом за базами життевого ичиклу підприємства. Доведено, що подальші дослідження доцільно проводити в напрямку розробки системи моніторингу та регулювання управлінських рішень по реалізащї потениіалу підприємства.

Ключові слова: потенціал, організащійне забезпечення, підприємство, управління, рачіональність.

Adis, CS (2017). Сприйнята організаційна підтримка: метааналітична оцінка теорії організаційної підтримки. Журнал управління , 43 (6), 1854-1884. https://doi. org/10.1177/0149206315575554

9. Chen, T., Hao, S., Ding, K., Feng, X., Li, G. and Liang, X. (2020), «The impact of organizational support on employee performance», Employee Relations, Vol. 42 No. 1, pp. 166-179. https://doi.org/10.1108/ER-012019-0079

10. Gaëtane Caesens, Florence Stinglhamber, Stéphanie Demoulin \& Matthias De Wilde (2017) сприймали організаційну підтримку та добробут працівників: посередницьку роль організаційної дегуманізації, European Journal of Work and Organtional Psychology, 26: 4, 527540, DOI: 10.1080 / 1359432X.2017.1319817

11. Система підтримки прийняття рішень https://msn.khnu.km.ua

12. Про організаційний розвиток простою мовою https://www.ua.undp.org/ content/ukraine/uk/home/library/democratic governance/demystifying-organisationaldevelopment.html

13. Управление знаниями: Эволюция и революция в орг. / Бенцион Захарович Мильнер. - М.: ИНФРА-М, 2003. - XIV, $177 \mathrm{c}$.

14. Зінкевич Д.К. Сутність креативного менеджменту і його місце в системі управління машинобудівним підприємством / Д.К. Зінкевич // Науковий вісник НЛТУ України. Випуск 19.2. - Львів. - 2009. -C. 182-187.

15. Зінкевич Д.К. Рішення щодо забезпечення розвитку креативного менеджменту підприємства як елемент інформаційно-комунікаційної системи / О.Е. Кузьмін, С.В. Князь, Н.Г. Георгіаді, Д.К. Зінкевич // Збірник наукових праць Дніпропетровського національного університету. Випуск 259. Том VII. Економіка: проблеми теорії та практики. - Дніпропетровськ. - 2010. С.1853-1861.

16. Інноваційні програми машинобудівних підприємств: креативні рішення і моделі їх трансферного забезпечення: [Монографія] / О.Е. Кузьмін С.В. Князь, А.Й. Гнилянська, Д.К. Зінкевич // Аьвів: Видавництво «СПОАОМ», 2010. - 345 c. 
Щебель А.І. - Організаційне забезпечення раціональної реалізації потенціалу...

\section{SUMMARY}

In addition to traditional components of organizationalsupport (formation of organizational structure of management, creation of rules and procedures in the organization, distribution of functions and powers in the personnel system), the article discusses the mechanism of development of creative initiatives in managing the potential of the enterprise. It is proved that this component is causally related to other components of organizational maintenance of rational realization of enterprise potential. It is substantiated that its accounting is caused by activation of integration processes, increase of the level of informatization of business and aggravation of competition. A built-in organizational security model requires consideration of factors that are common to all its components. In particular, when making local decisions in the responsibility centers associated with a particular component of the system. The organizational development of the enterprise is largely related to the phase of the life cycle of the enterprise. Each of the components of the system set of organizational maintenance of rationality of realization of potential of the enterprise is active throughout the life cycle of development of the enterprise. But the onset of the final phase of development is a sign of the lack or weakness of the enterprise-based mechanism for developing creative initiatives in managing the enterprise's potential. It is substantiated that the parameters of the model of organizational support of rational realization of the potential of the enterprise requires quantitative parameterization, especially for making sound decisions related to capacity management by the phases of the life cycle of the enterprise. It is proved that further research is advisable to carry out in the direction of developing a system of monitoring and regulation of management decisions to realize the potential of the enterprise.

Keywords: potential, organizational support, enterprise, management, rationality. 